\title{
Comparison of hypersensitive plum rootstocks
}

\author{
PETER HILSENDEGEN \\ Dienstleistungszentrum Ländlicher Raum Rheinpfalz, Oppenheim, Germany \\ peter.hilsendegen@dlr.rlp.de
}

\begin{abstract}
Summary
New bred plum rootstocks are compared with 'Prudom' as a growing standard. Combined with 'Cacanska lepotica' and 'Jojo' the rootstocks 'Prudom', 'Dospina 235' and 'Docera 6' were involved in this comparison. Following the first five years, no variant showed inaffinity. The vegetative performance of 'Prudom' and 'Dospina 235 ' was in the same range $( \pm 5-10 \%)$. 'Docera 6 ' shows vigour reduction (12-14\%). 'Prudom' and 'Dospina 235' are also in the same range of generative performance ('Cacanska lepotica' $-19 \%$, 'Jojo' $+4 \%$ ). The cumulated yield in Docera $6^{\prime}$ was more or less half quantity. The results of the first five years are too young for valid practical advice. Furthermore, it opens the perspective for alternative rootstock of prune industry in areas with high virus pressure.
\end{abstract}

Keywords: plum rootstock, hypersensitivity, plum pox virus

\section{Introduction}

The breeding of hypersensitive individuals of plume cultivars offers new opportunity for plum industry in areas with high virus (plum pox virus) pressure. Using combination of hypersensitive cultivar with hypersensitive rootstock can exclude virus vulnerability in tree propagation and fruit production. Provided the properties of these cultivars and rootstocks are compatible with industry demands. Evaluation of available cultivars and rootstock are needed to compare it with standard material.

\section{Material and methods}

The comparison of rootstocks included the follow rootstocks.

'Prudom' - Wavit ${ }^{\circledR}$ as standard rootstock for most of German growing condition. 'Dospina 235', a hypersensitive rootstock, bred by Dr. Michael Neumüller. 'Docera 6', a hypersensitive rootstock, bred by Dr. Michael Neumüller. The rootstocks are combined with the cultivars 'Cacanska lepotica' and 'Jojo'. Each treatment counts 6 trees divided in 2 replications with 3 trees. The treatments are carried out at experimental station for fruit growing Oppenheim DLR Rheinpfalz, located in the Southwest of Germany. 


\section{Results and discussion}

The evaluation measured the tree performance in order to observe if the treatments are competitive on standards. After first five years of evaluation no variant shows incompatibility. Vegetative performance of 'Prudom' and 'Dospina 235' was in the same range $( \pm 5-10 \%)$. 'Docera 6' shows vigour reduction (12-14\%). 'Prudom' and 'Dospina 235' are also in the same range of generative performance ('Cacanska lepotica' $-19 \%$, 'Jojo' $+4 \%$ ). The cumulated yield in Docera 6' was more or less the half quantity.

The results of the first five years are too young for valid practical advice. Actually it opens the perspective for alternative rootstock of plum industry in areas with high virus pressure. Together with different other experimental results a valid advice should possible in few years.

\section{Conclusion}

The results of first 5 years are not enough for final conclusion. Because of similar performance to 'Prudom' looks 'Dospina 235' more interest for the actual most used orchard system. If the first impression would confirmed the next years, a new substitution to the standard could developed. Successful combinations of hypersensitive cultivars and rootstock have potential to eliminate the most virus problems of plum industry in future.

\section{References}

Hartmann, W. (2016): Control of Sharka: Control and prevention measures in the last four decades, ISHS: VI International Symposium on plum and prune genetics, breeding and pomology.

Neumüller, M. (2012): Neues aus der Zwetschenforschung. Tagungsband Bundesseminar Steinobst 2012. DLR Rheinpfalz.

Wertheim, S. J. (1998): Rootstock Guide. FPO Wilhelminadorp. 